By the use of Gimmingham's form of pump the exhaustion can be increased in a very short time, and the readings all obtained from one cylinder an inch in diameter. Three series of readings were taken agreeing very well with each other. At first there were discrepancies, owing to the porosity of the cylinder not being noticed, but these disappeared when care was taken. The temperatures were not corrected, as the results were not intended for publication, as I expected some other worker to repeat the experiment, but that not being the case I give the numbers as they are, premising that the temperatures, if corrected, would be $6^{\circ}$ or $7^{\circ}$ higher for the upper and $4^{\circ}$ to $6^{\circ}$ for the lower ones. The following are the numbers obtained :-

\begin{tabular}{rrrrrrrrrr}
$\begin{array}{c}\text { Pressure in } \\
\text { millimetres. }\end{array}$ & \multicolumn{3}{c}{$\begin{array}{c}\text { Temperature of } \\
\text { volatilisation. }\end{array}$} & \multicolumn{3}{c}{$\begin{array}{c}\text { Pressure in } \\
\text { millimetres. }\end{array}$} & $\begin{array}{c}\text { Temperature of } \\
\text { volatilisation. }\end{array}$ \\
400 & $\ldots$ & $\ldots$ & 270 & $\ldots$ & $\ldots$ & 40 & $\ldots$ & $\ldots$ & 233 \\
300 & $\ldots$ & $\ldots$ & 267 & $\ldots$ & $\ldots$ & 30 & $\ldots$ & $\ldots$ & 228 \\
200 & $\ldots$ & $\ldots$ & 263 & $\ldots$ & $\ldots$ & 20 & $\ldots$ & $\ldots$ & 223 \\
100 & $\ldots$ & $\ldots$ & 253 & $\ldots$ & $\ldots$ & 10 & $\ldots$ & $\ldots$ & 214 \\
80 & $\ldots$ & $\ldots$ & 248 & $\ldots$ & $\ldots$ & 5 & $\ldots$ & $\ldots$ & 205 \\
60 & $\ldots$ & $\ldots$ & 242 & $\ldots$ & $\ldots$ & 0 & $\ldots$ & $\ldots$ & 185
\end{tabular}

A determination done before those given above gave-

\begin{tabular}{cccccc}
$\begin{array}{c}\text { Pressure in } \\
\text { millimetres. }\end{array}$ & & & & \multicolumn{2}{c}{$\begin{array}{c}\text { Temperature of } \\
\text { volatilisation. } \\
68\end{array}$} \\
10 & $\ldots$ & $\ldots$ & $\ldots$ & $\ldots$ & 245 \\
5 & $\ldots$ & $\ldots$ & $\ldots$ & $\ldots$ & $\mathbf{2 2 2}$ \\
& $\ldots$ & $\ldots$ & $\ldots$ & 210
\end{tabular}

But I do not place the same confidence on these numbers, as they were obtained in ignorance of the porosity of the solid; but they confirm the others. It appears from the above that mercuric chloride is no exception to the general law which makes the volatilising point rise or fall with the pressure. The low latent and specific heats of mercuric chloride make it not nearly so suitable an exponent of the truth of Regnault's corclusions as water; the latter allowing of a whole hour's continued experiment. I think after these experiments the idea of being able to raise solids in vacuo to temperatures above their ordinary volatilising or boiling points may lie dismissed as inadmissible, except it may be in some rare case of allotropy.

Private Laboratory, Sword Street, Glangow J. B. HANNAY

\section{The Conservation of Electricity}

By the kind permission of Messrs. Macmillan and Co. I am allowed to quote the following paragraph from the preface to my "Elementary Lessons in Electricity and Magnetism," shortly to be published by them in their School Class Books Series, and now in the press. The preface is dated "March, 188I."

"The theory of Elestricity adopted throughout is that Electricity, whatever its nature, is one, not two : that Electricity, whatever it may prove to be, is not matter, and is not energy: that it resembles both matter and energy in one respect, however, in that it can neither be created nor destroyed. The doctrine of the Conservation of Matter, established a century ago by Lavoisier, teaches us that we can neither destroy nor create matter, though we can alter its distribution and its forms and combinations in innumerable ways. The doctrine of the Con. servation of Energy, which has been built up by Helmboltz, Thomson, Joule, and Mayer, during the last half century, teaches us that we can neither create nor destroy energy, though we may change it from one form to another, causing it to appear as the energy of moving bodies, as the energy of heat, or as the static energy of a body which has been lifted against gravity or some other attracting force into a position whence it can run down, and where it has the potentiality of doing work. So also the doctrine of the Conservation of Electricity, which is now growing into shape, ${ }^{1}$. but here first enunciated under this name, teache us that we can neither create nor destroy electricity, though we may alter its distribution-may make more to appear at one place and less at another-may change it from the condition of rest to that of motion, or may cause it to spin round in whirlpools or vortices which themselves can attract or repel other vortices. According to this view all our electrical machines and batteries are merely instruments for altering the distribution of electricity

I This is undoubtedly the outcome of the ideas of Maxwell and of Faraday as to the nature of electricity. It has nowhere been more excellently or pithily put into shape than in a discourse delivered by Dr. Oliver J. Lodge before the "London Institution, "On the Relation between Light and Electricity," December 16, I880 (NATURE, vol. xxiii. p 302). by moving some of it from one place to another, or for causing electricity, when heaped up in one place, to do work in returning to its former level distribution. Thruughout these Les;ons the attempt has been made to state the facts of the science in language consonant with this view, but rather to lead the young student to this as the result of his study than to insist upon it dogmatically at the outset."

The above paragraph is published at the present time because, since the date when my manuscript was sent to the publishers, a memoir has been presented to the Académie des Scieaces bearing the title, "Sur le Principe de la Conservation de l'Électricité, ou seconde Principe de la Théorie des Phénomènes Électriques." Of this memoir, which is by M. G. Lippmann, only a brief extract has as yet been published in the Comptes rendus of the sitting of May 2, when it was read. In that short extract the general doctrine of the conservation of electricity is laid down with considerable clearness, and an elegant analytical expression of it is given in the briefest form, the author promising some examples of its application to the prediction of new and important phenomena. The publication of the complete memoir of M. Lippmann will no doubt be awaited with interest.

As my manuscript was placed in the hands of Messrs. Macmillan and $C_{0}$. on the very day when the above extract was written, the phraseology used by M. Lippmann must have been adopted by him in entire independence of me. Since some weeks must elapse before my "Elementary Lessons" will be in the hands of the public, I wish to avoid, meantime, all chance of misunderstanding by taking the earliest opportunity, firstly, of making this acknowledgment, which is due to M. Lippmann, and secondly, of establishing my right to use the language of my preface as to the explicit enunciation of the doctrine of the Conservation of Electricity.

University College, Bristol, May I9

\section{The Florence Herbarium}

I BEG to forward to you the inclosed protest of the botanists of Florence against the proposed removal of the Herbarium and adjoining Botanical Garden at Florence to a new locality in that city.

It is well known to all botanists who have visited that city that, taking into account the importance of the herbarium, the admirable building in which this and the other collections are lodged, and the annexed botanical garden, the establishment at Florence deserves to rank amongst the first in the world, and is indeed scarcely second to any except that at Kew. It has an especial interest in the eyes of Englishmen, owing to the fact that it includes the invaluable collections of the late $\mathrm{Mr}$. Barker Webb, which include, besides the type specimens of the Canary Island flora and of his other works, those still more important of Labillardière, of Rinz and Pavon, and of Desfontaines, whose herbaria all passed into his hands.

Although well acquainted with the Florence Museum, and disposed to believe that it would be difficult to find another locality equally well adapted for the purpose, I was unwilling to express any opinion on the subject without full information as to the new arrangements proposed in substitution for those now so excellent.

Witbin the last month my friends Sir Joseph Hooker and Dr. Asa Gray have visited Florence, and have carefully examined the present building and its appurtenances, and also the sites to which it is proposed to remove the herbarium and botanic garden. I learn that they have expressed an unqualified opinion that the proposed new building is altogether unsuited for the purpose, and would too probably tend to the injury and ultimate loss of the herbarium, while the site of the proposed botanic garden is also an unfavourable one.

Sir Joseph Hooker has written a full statement of his views to Prof. Carnel, recently appointed Director of the Botanical Museum, who has not, I believe, as yet published his opinion on the subject.

Under these circumstances I venture to hope that you will publish the accompanying document, with a view to prevent the accomplishment of a design so injurious to natural science. Those who wish to associate their names with the protest are invited to send them to M. E. Sommier, Lung'Arno, Corsini, Florence.

ro, Southwell Gardens, London, S.W., May 20 